IDEA - Studia nad strukturą i rozwojem pojęć filozoficznych $\mathrm{XXIX/1}$

Białystok 2017

\title{
Tomasz Kubalica
}

(Katowice)

\section{GENEZA I PODSTAWY FILOZOFII MATEMATYKI KRYTYCZNEJ LEONARDA NELSONA*}

Leonard Nelson (1882-1927) w obszernym liście z 29 grudnia 1916 roku adresowanym do swojego starszego o dwadzieścia lat mentora Davida Hilberta (1862-1943) przedstawił swój manifest zatytułowany Mein Glaubensbekenntnis (Moje wyznanie wiary) dotyczący możliwości naukowego uprawiania filozofii w Niemczech ${ }^{1}$. Zawarł w nim cele swoich dotychczasowych filozoficzno-naukowych dążeń i opisał najważniejsze przeszkody. Jego celem była rehabilitacja filozofii na podstawie metod matematyki i nauk przyrodniczych oraz walka $z$ dogmatem o niemożliwości uprawiania filozofii jako nauki.

Mimo przyjacielskich relacji z Hilbertem głównym źródłem filozoficznych inspiracji Nelsona była jednak myśl Jakoba Friedricha Friesa (1773-1843)², która powstała w ścisłym związku z filozofią krytyczną Immanuela Kanta (17241804), ale w opozycji do filozofii Georga Wilhelma Friedricha Hegla (17701831) i niemieckiego idealizmu. W dziełach Friesa takich jak Versuch einer Kri-

* Projekt został sfinansowany ze środków Narodowego Centrum Nauki przekazanych na podstawie decyzji numer DEC-2013/11/B/HS1/03937.

${ }^{1}$ Por. V. Peckhaus, Hilbertprogramm und Kritische Philosophie. Das Göttinger Modell interdisziplinärer Zusammenarbeit zwischen Mathematik und Philosophie, Vandenhoeck \& Ruprecht, Göttingen 1990, s. 123 i nast.

${ }^{2}$ Zob. A.J. Noras, Historia neokantyzmu, Wydawnictwo Uniwersytetu Śląskiego, Katowice 2012, s. 345 i nast. 
tik der Principien der Wahrscheinlichkeitsrechnung $(1842)^{3}$, Die mathematische $\mathrm{Na}$ turphilosophie nach philosophischer Methode bearbeitet: ein Versuch (1822) ${ }^{4}$ i System der Logik: Ein Handbuch für Lehrer und zum Selbstgebrauch (1837) $)^{5}$ Nelson dostrzega „personalną unię” trzech dziedzin wiedzy: filozofii, matematyki i fizyki.

Fries w swoich pierwszych dziełach podejmuje krytyczną analizę założeń filozofów idealizmu niemieckiego i postuluje „pre-neokantowski” powrót do Kanta. Najważniejsze zarzuty Friesa dotyczą uznania przez idealistów niemieckich możliwości poznania bezpośredniego w naoczności intelektualnej; dla niego wszelka naoczność może być wyłącznie zmysłowa. Prace Friesa dotyczące filozofii natury oraz filozofii matematyki powstały w okresie jego Heidelberskiego epizodu (1805-1816), który zaowocował pracami takimi jak między innymi Entwurf des Systems der theoretischen Physik ${ }^{6}$ z 1813 roku a później powyżej wymienionymi przez Nelsona. Zwrot dokonuje się w Neue Kritik der Vernunft w 1807 roku, kiedy Fries podnosi postulat nowego, antropologicznego ugruntowania filozofii, w którym podstawową rolę odgrywa doświadczenie wewnętrzne. $Z$ powodu swej krytyki idealizmu oraz zwrotu ku antropologii został uznany przez Kuno Fischera (1824-1907) w 1869 roku za psychologistę, co stanowiło poważny zarzut odstępstwa od doktryny Kanta. Głównym problemem jest jednak kwestia rozumienia doświadczenia wewnętrznego. Fries zarzucił Kantowi, że jego koncepcja poznania a priori nie uwzględnia jego psychologicznej natury. Kant próbował aprioryczne poznanie transcendentalne i jego obiektywną ważność udowodnić przy pomocy dedukcji transcendentalnej. Błędność takiego podejścia zauważył nie tylko Fries, lecz również Carl Gustav Jacobi (1804-1851). Mimo to $\mathrm{w}$ rozważaniach Friesa granica pomiędzy empiryczną psychologią a psychiczną antropologią nie jest jasno postawiona. Podstawowa jest kwestia bezpośredniego poznania form apriorycznych, które w jego ujęciu dokonuje się przez doświadczenie wewnętrzne. Fries wychodzi poza Kantowski dualizm poznania w naoczności i poznania w pojęciu w ten sposób, że uznaje istnienie trze-

${ }^{3}$ Jakob Friedrich Fries, Versuch einer Kritik der Principien der Wabrscheinlichkeitsrechnung, Friedr. Vieweg u. Sohn, Braunschweig 1842.

${ }^{4}$ J.F. Fries, Die mathematische Naturphilosophie nach philosophischer Methode bearbeitet: ein Versuch, Mohr und Winter, Heidelberg 1822.

${ }^{5}$ J.F. Fries, System der Logik: Ein Handbuch für Lehrer und zum Selbstgebrauch, Mohr und Zimmer, Heidelberg 1837, 3. wyd.

${ }^{6}$ J.F. Fries, Entwurf des Systems der theoretischen Physik. Zum Gebrauche bey seinen Vorlesungen, Mohr und Zimmer, Heidelberg 1813. 
ciego (bezpośredniego) poznania danego w ludzkim wnętrzu, które nazywa „ciemnymi” przedstawieniami, do których należy zwłaszcza „bezpośrednie niewypowiedziane poznanie własne rozumu" ". Fries próbuje na drodze antropologicznej i aposteriorycznej rozwiązać kwestię poznania form i kategorii apriorycznych.

Nelson zainspirowany filozofią i niezłomną postawą Friesa bardzo wcześnie podjął studia nad podstawami nauk ścisłych, które objęły przede wszystkim podstawowe zagadnienia matematyki ${ }^{8}$. Doniosłą rolę odegrał tutaj Gerhard Hessenberg', przyjaciel Nelsona i jednocześnie młody asystent w Wyższej Szkole Technicznej w Charlottenburgu, z którym omawiał on aksjomatyczne podstawy systemu geometrii na podstawie Grundlagen der Geometrie Hilberta. Rozmowy z Hessenbergiem skierowały młodego Nelsona do Getyngi, która stanowiła centrum badań matematycznych od Gaussa do Hilberta. Sam Nelson nie tylko wiele się nauczył w kręgu getyngeńskich matematyków, lecz również stał się liderem współpracy naukowej między matematykami a filozofami. W ten sposób starał się urzeczywistniać idę filozofii jako nauki aż do przedwczesnej śmierci w 29 października 1927 roku.

Geneza związków Nelsona z matematyką sięga początków jego pobytu w Getyndze, kiedy poznał swoich pierwszych przyjaciól, z którymi dyskutował kwestie filozoficzne w ramach Nowej Szkoły Friesa, do której zaliczali się

${ }^{7}$ J.F. Fries, Neue Kritik der Vernunft, Mohr und Zimmer, Heidelberg 1807, t. I, s. 206.

${ }^{8}$ V. Peckhaus, Hilbertprogramm und Kritische Philosophie..., dz. cyt.., s. 124.

${ }^{9}$ Gerhard Wilhelm Hessenberg (1874-1925) uczęszczał do szkół we Frankfurcie nad Menem. Studia z fizyki podjął pierwotnie w Strasburgu. Po trzecim semestrze poświecił się całkowicie matematyce w Berlinie głównie pod kierunkiem Hermanna Amandusa Schwarza, dzięki któremu poznał również Ernsta Zermelo. Hessenberg doktoryzował się w roku 1899 a w 1901 roku habilitował się z geometrii wykreślnej w Wyższej Szkole Technicznej w Charlottenburgu (Technischen Hochschule Charlottenburg), mimo to poświecił się czystej matematyce. Hessenberg udzielał się także w środowisku matematyków berlińskich i należał do grona 38 członków założycieli założonego w 1901 roku Berlińskiego Towarzystwa Matematycznego (Berliner Mathematischen Gesellschaft). W 1904 roku uzyskał stanowisko nauczyciela matematyki w Wojskowo-Technicznej Akademii w Charlottenburgu (Militärtechnischen Akademie in Charlottenburg) a niewiele później - tytuł profesora. Latem 1910 roku został powołany na katedrę geometrii wykreślnej i statystyki graficznej w Technicznej Szkole Wyższej we Wrocławiu (Technische Hochschule in Breslau), gdzie w 1914 został rektorem, ale tylko przez 2 lata. W 1918 roku został jednocześnie powołany na nowo utworzoną katedrę matematyki stosowanej w Tybindze oraz na Uniwersytet w Berlinie. Powołanie do Berlina odrzucił i przeniósł się do Tybingi z przyczyn rodzinnych, ponieważ tam jego teściowie znaleźli schronienie po wypędzeniu ze Strasburga. 
wspomniany Gerhard Hessenberg, a także Otto Meyerhof, Heinrich Goesch, Alexander Rüstow i Kurt Grelling. Pierwsi czterej należeli do członków założycieli szkoły. Grelling dołączył dopiero w semestrze zimowym 1905/06, ale stał się najbliższym współpracownikiem Nelsona przy rozważaniach nad podstawowymi problemami matematyki, a także pod względem politycznym ${ }^{10}$.

Punktem ogniskującym życie intelektualne badaczy związanych z Nelsonem stało się wznowione czasopismo Abhandlungen der Fries'schen Schule, które stało się forum wymiany myśli między zwolennikami Nowej Szkoły Friesa ${ }^{11}$. Pierwotnie seria wydawana była w latach 1847-1849 przez uczniów Friesa takich jak Ernst Friedrich Apelt (1812-1859), Matthias Jakob Schleiden (18041881), Oscar Xavier Schlömilch (1823-1901) i Oscar Schmidt (1823-1886). Doczekała się ona tylko dwóch zeszytów i została przerwana przez wydawcę Wilhelma Engelmanna z przyczyn politycznych ${ }^{12}$. Nowa seria Abhandlungen der Fries'schen Schule zainicjowana została przez Nelsona, który podjął się tego jeszcze jako dwudziestolatek przed egzaminem doktorskim, we współpracy z matematykiem Hessenbergiem i fizjologiem Karlem Kaiserem, co świadczy o ponaddyscyplinarnym charakterze czasopisma ${ }^{13}$. Zmienił się również wydawca, którym został Vandenhoeck \& Ruprecht.

Redaktorzy przedmowy do reaktywowanego czasopisma deklarują w niej, $\dot{z} e$ „ugruntowana przez Kanta i kontynuowana przez Friesa i Apelta filozofia nie została przezwyciężona przez historię i że nigdy nie może zostać przezwyciężona. ${ }^{14} \mathrm{Na}$ ponadczasowe znaczenie metody krytyki rozumu wskazują zarówno wstęp do starej, jak i do nowej serii. Tak proklamowany powrót do Friesa miał stanowić wyraz dezaprobaty wobec błędnego kierunku niemieckiej filozofii reprezentowanego nie tylko przez Fichtego, Hegla, Schellinga, ale również Schopenhauera i Nietzschego ${ }^{15}$.

${ }^{10}$ V. Peckhaus, Hilbertprogramm und Kritische Philosophie..., dz. cyt., s. 132.

${ }^{11}$ E.F. Apelt et al., red., Abhandlungen der Fries'schen Scbule, Verlag von Wilh. Engelmann, Leipzig 1847, t. 1; E.F. Apelt et al., red., Abhandlungen der Fries'schen Schule, Verlag von Wilh. Engelmann, Leipzig 1849, t. 2.

${ }^{12}$ V. Peckhaus, Hilbertprogramm und Kritische Philosophie..., dz. cyt., s. 150.

${ }^{13}$ G. Hessenberg, K. Kaiser, i L. Nelson, red., Abhandlungen der Fries'schen Schule. Neue Folge, Vandenhoeck \& Ruprecht 1906, t. 1.

${ }^{14}$ L. Nelson, G. Hessenberg, i K. Kaiser, Vorwort der alten Folge zugleich als Vorwort der neuen Folge, „Abhandlungen der Fries'schen Schule. Neue Folge”, 1904, t. 1, nr 1, s. VII-VIII.

${ }^{15}$ T. Kubalica, Die Beziehung zwischen dem Lehrmeister und dem Schüler in der neukantischen Philosophie, „Idea - Studia nad Strukturą i Rozwojem Pojęć Filozoficznych”, 2015, t. XXVII, s. 386. 
Drugim nie mniej istotnym przedsięwzięciem integrującym neofriesjanistów stało się założenie Towarzystwa Jakoba Friedricha Friesa (Jakob Friedrich Fries-Gesellschaft), które poprzedzała nieformalna wspólnota nazywana Nową Szkoła Friesa powstała w ośrodkach akademickich takich jak Getynga, Berlin czy Heidelberg ${ }^{16}$. Żeby uniknąć rozdrobnienia Nelson już w święta Bożego Narodzenia w 1907 roku wpadł na pomysł założenie organizacji, która nada nieformalnym strukturom życia akademickiego postać bardziej zorganizowaną, o czym już w marcu 1908 roku zawiadomił przyjaciela Hessenberga. Taką organizacją miałoby być pierwotnie Towarzystwo Filozofii Krytycznej (Gesellschaft für kritische Philosophie), którego najważniejsze cele i zasady przedstawił w dziesięciopunktowym programie zakładającym uznanie następujących postulatów: (1) niezmienności podziału na sądy analityczne i syntetyczne, (2) niesamoistności myślnego poznania i refleksji, (3) sądów syntetycznych a priori w matematyce i przyrodoznawstwie, czyli odrzucenie empiryzmu, (4) źródłowej niejasności (Dunkelheit) poznania metafizycznego, (5) postulatu krytyki czystego rozumu, (6) logicznej niezależności filozofii od psychologii i biologii, (7) postulatu metafizyki moralności, (8) autonomii moralności, (9) naturalnej formy ludzkiego poznania i (10) rozumnej wiary wraz z naukowym poznaniem. Volker Peckhaus uważa, że pierwsze dwa punkty były skierowane przeciwko neokantyzmowi, filologii i historii myśli Kanta, drugi i czwarty przeciwko idealistom niemieckim (Fichtemu, Heglowi i Schellingowi), piąty przeciwko dogmatyzmowi Meinonga, Husserla, Itelsona i Couturata, szósty przeciwko psychologizmowi, dziewiąty przeciwko neowitalizmowi a trzeci został wprowadzony, żeby zachęcić Frege$\mathrm{go}^{17}$.

Założenie towarzystwa zostało jednak odłożone i grupa funkcjonowała w mniej formalny sposób jako Nowa Szkoła Friesa, której zebranie założycielskie odbyło się 5 sierpnia 1908 roku podczas 3. Międzynarodowego Kongresu Filozoficznego w Heidelbergu. Spotkania odbywały się regularne do wybuchu pierwszej wojny światowej. Na przełomie lat 1912 i 1913 Nelson powrócił do zamiaru utworzenia stowarzyszenia pod nazwą Towarzystwo Jakoba Friedricha Friesa (Jakob Friedrich Fries-Gesellschaft). Jego statut został opracowany pod kierunkiem Otto Apelta, Paula Bernaysa, Marcela T. Djuvara, Gerharda Hessenberga i Otto Meyerhofa. Zebranie założycielskie (datowane na 1 marca 1913

\footnotetext{
${ }^{16}$ V. Peckhaus, Hilbertprogramm und Kritische Philosophie...,dz. cyt., s. 152.

${ }^{17}$ Tamże, s. 153.
} 
roku) odbyło się od 3 do 7 marca 1913 roku. Postulaty nowo założonego towarzystwa nie były tak restrykcyjne jak w pierwotnym zamierzeniu Nelsona. Jego zadaniem stało się „wspieranie ugruntowanej przez Kanta i Friesa filozofii krytycznej na drodze rozbudowy wspólnoty intensywnej pracy w ramach Szkoły Friesa, jak również poprzez rozszerzenie tej filozofii na zewnątrz i wsparcie tych dążeń, które stawiają sobie za zadanie jej zastosowanie w konkretnych kwestiach teoretycznych i praktycznych.”18

\section{Metoda krytyczna}

W centrum refleksji Nowej Szkoły Friesa, a także Towarzystwa Friesa znajduje się Kantowskie pojęcie metody krytycznej. Inspiracją Nelsona była odrodzona w krytycznej metodzie Kanta koncepcja metody sokratycznej w ujęciu Platona i Sokratesa ${ }^{1920}$ Nelson uważa, że Kant i Fries uwolnił metodę sokratejską od wpływów platońskiego mistycyzmu „ku spójnej i niezbicie pewnej formy nauki” przez to, że udoskonalili oni regresywną metodę abstrakcji na drodze tak zwanej dedukcji, w której odrodziła się nauka o anamnezie ${ }^{21}$. Metodę krytyczną Nelson zgodnie z neofriesjańską tradycją Kantowską przeciwstawia postępowaniu dogmatycznemu następująco:

Jeżeli zatem nazwiemy dogmatycznym postępowanie nauki, która wychodzi od ustanowienia swych pryncypiów, krytycznym zaś postępowanie nauki, która poddaje sprawdzeniu nawet swoje pryncypia, to będziemy mogli powiedzieć, że w filo-

${ }^{18}$ Cytat za: tamże., s. 154.

${ }_{19}$ R.M. Chisholm, Die sokratische Methode und die Erkenntnistheorie, „Ratio”, 1979, nr 21, s. 97-108; J. Schroth, Regressive Methode der Abstraktion und unmittelbare Erkenntnis bei Leonard Nelson, [w:] Leonard Nelson in der Diskussion, red. R. Kleinknecht i B. Neißer, Dipa-Verlag, Frankfurt am Main 1994, t. 1, "Sokratisches Philosophieren« Schriftenreihe der PhilosophischPolitischen Akademie, s. 114-152; H. Wahler, Sokratische Methode - Sokratischer Dialog - Sokratisches Gespräch. Zur Anwendung in Philosophischer Psychologie Praxis, Pädagogik und Psychotherapie, „e-Journal Philosophie der Psychologie”, b.d., s. 1-10.

${ }^{20}$ Por. L. Nelson, Metoda sokratyczna, [w:] O sztuce filozofowania, przeł. P. Waszczenko i T. Kononowicz, Wydawnictwo Baran i Suszyński, Kraków 1994, s. 167.

${ }^{21}$ L. Nelson, Die sogenannte neukantische Schule in der gegenwärtigen Philosophie, [w:] Gesammelte Schriften in neun Bänden: Die Schule der kritischen Philosophie und ibre Methode, Hamburg 1970, t. 1, s. 290. 
zofii wszystko zależy od postępowania krytycznego, a krytycyzm w filozofii polega na przestrzeganiu metody regresywnej. ${ }^{22}$

Nelson nawiązuje tym samym do Kantowskiej krytyki czystego rozumu, która polegała na wykazaniu uzasadnienia dla sądów metafizycznych na podstawie warunków ich możliwości ${ }^{23}$. Nelsonowska koncepcja metody krytycznej opiera się na jego kontradyktoryjnym rozumieniu filozofii jako sporu o pryncypia, które stanowią często nieświadome założenie deklarowanych sądów i ocen. Te zasady muszą zostać wydobyte i sprawdzone na postawie metody regresywnej, oznaczającej proces abstrahowania, który nie dostarcza dowodów w rozumieniu „progresywnego wyprowadzenia wniosków z ich racji”, lecz przeciwnie przejścia od wniosków do ich racji. Dowód oznacza tutaj zatem wnioskowanie, w którym teza lub twierdzenie zostało przyjęte słusznie na podstawie twierdzeń podstawowych. Podejście Nelsona opiera się na następującym przekonaniu:

Jest całkowicie błędnym przesądem logicznym, że wszelka prawda musi mieć swój dowód. Raczej żadne dowody nie pozwolą nam poznać ani odkryć niczego, co nie zawierałoby się już implicite w zasadach, możemy sobie to jedynie uwyraźniać i jaśniej uświadomić. Dowody są konieczne i możliwe jedynie dla pośrednich, wyprowadzonych twierdzeń, lecz tyleż niepotrzebne, co niemożliwe dla zasad. ${ }^{24}$

Dałoby się kwestionować założenia każdego twierdzenia, aż do osiągnięcia całkowitej pewności, aby osiąnąć najwyższe pryncypia w klarownej postaci. Metoda regresywna służy do wydobywania podstaw naszych sądów i ocen $\mathrm{w}$ formie jasnych i świadomie wyrażonych pryncypiów. Metoda ta jest stosunkowo prosta w sądach opartych na podstawie naoczności. Podstawowy problem polega na tym, że nasze poznanie tylko częściowo opiera się na naoczności, gdyż posiada również nienaoczny składnik w postaci zawartych w sądach pojęć. Zadaniem filozofii jako nauki jest odkrycie tych czystych twierdzeń podstawowych $\mathrm{i}$ ich wyprowadzenie. Filozofia pozbawiona regresji popada w arbitralność dogmatycznej metafizyki. Jednak nie każda regresja jest odpowiednia i dlatego

${ }^{22}$ L. Nelson, Metoda krytyczna i stosunek psychologii do filozofii, [w:] O sztuce filozoforwania, przeł. P. Waszczenko i T. Kononowicz, Wydawnictwo Baran i Suszyński, Kraków 1994, s. 48.

${ }^{23}$ Zob. T. Kubalica, Leonard Nelson and Metaphysical Knowledge against the Neo-Kantian Background, „Diametros”, 2017, nr 52, s. 67 i nast. (DOI: dx.doi.org/10.13153/diam. 52.2017.1059).

${ }^{24}$ L. Nelson, „Metoda krytyczna i stosunek psychologii do filozofii”, dz. cyt., s. 47. 
Nelson odróżnia indukcje od abstrakcji ${ }^{25}$. Problem z indukcją polega na tym, że może ona tylko wyprowadzać twierdzenia, a nie podstawowe i konieczne pryncypia, ponieważ w metodzie indukcyjnej uniwersalne prawa muszą być już założone. Droga do apriorycznych praw uniwersalnych jest abstrakcja, która oznacza ujęcie powszechnych i koniecznych pryncypiów w tym, co szczegółowe. W ten sposób wyprowadzone na podstawie indukcji Newtonowskie prawo grawitacji łączy obserwacje astronomiczne $z$ ogólnymi zasadami mechaniki opartymi na stanowiących ich założenie - nieindukcyjnych - pryncypiach matematycznej filozofii przyrody.

Ta sama kwestia metody krytycznej odnosi się również do filozofii samej, w której również trzeba poszukiwać i przyjmować określone pryncypia, co nieuchronnie prowadzi ją do pewnego rodzaju błędnego koła, gdyż musi ona regresywnie lub progresywnie zakładać to, co chce udowodnić ${ }^{26}$. To oznacza, że może ona popaść albo w dogmatyzm, kiedy bezkrytyczne przyjmuje jakieś stanowisko albo w sceptycyzm, gdy go równie bezkrytycznego odrzuca. Wyjście z tego zamkniętego kręgu polega według Nelsona na zastosowaniu metody krytycznej, gdy filozofia nie próbuje udowadniać, lecz jedynie „wskazywać” swoje pryncypia:

„Nie udowadnia ona, lecz raczej szuka właśnie tego, co zakładamy już przy wszelkim dowodzeniu i co z konieczności musimy założyć."27

Różnica między podejściem krytycznym a bezkrytycznym odpowiada rozróżnieniu między dowodzeniem a wskazywaniem koniecznych warunków wszelkich dowodów. Filozofia krytyczna wychodzi zatem „wyłącznie od faktów, przyjmując stan faktyczny naszych sądów tak, jak go zastaje, oraz rozpatrując go i analizując, aby wypowiedzieć explicite to, co już jest w nim implicite zawarte"28. Filozofia krytyczna wykazuje zatem konieczne i przyjęte implicite warunki eksplicytnie zawartego w sądach stanu wiedzy.

Jednocześnie Nelson wyznacza stosunek filozofii krytycznej do innych rodzajów wiedzy szczegółowej, którą zajmują się nauki indukcyjne. Filozofia kry-

25 Tamże, s. 48-49.

${ }^{26}$ Zob. T. Kubalica, Unmöglichkeit der Erkenntnistheorie. Leonard Nelsons Kritik an der Erkenntnistheorie unter besonderer Berücksichtigung des Neukantianismus, Peter Lang, Frankfurt am Main 2017, s. 94 i nast. (DOI: dx.doi.org/10.3726/b10702).

${ }^{27}$ L. Nelson, „Metoda krytyczna i stosunek psychologii do filozofii”, dz. cyt., s. 50.

${ }^{28}$ Tamże. 
tyczna nie posiada własnej dziedziny, gdyż odnosi się do wszystkich dziedzin wiedzy naukowej ${ }^{29}$, którą po neokantowsku przyjmuje jako fakt kulturowy, jaki należy wyjaśnić przez podanie najwyższych pryncypiów, a także - logicznie, albo empirycznie i genetycznie - weryfikować fakt poznania. Nie wiadomo jednak, jak interpretować Nelsonowskie ujęcie istoty filozofii krytycznej, która z jednej strony ma chronić przed błędami, choć z drugiej strony jako nauka pozbawiona własnego przedmiotu nie może dowodzić prawd. Pojawia się zatem pytanie, jak filozofia krytyczna ma chronić przed fałszem bez możliwości weryfikacji danego sądu przez porównanie $\mathrm{z}$ przedmiotem.

Wbrew wielusetletniej tradycji zainicjowanej jeszcze przez Arystotelesa Nel-

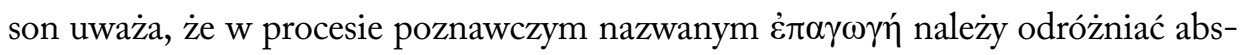

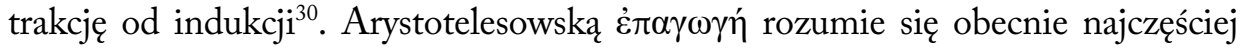
jako proces umysłowy indukcji przechodzenia od konkretnego przypadku do ogólnej zasady i utożsamia się ten proces $\mathrm{z}$ abstrakcją, która polega na niedyskursywnym przejściu od szczegółu do ogółu, w którym umysł intuicyjnie ujmuje istotę przedmiotów danych w doświadczeniu zmysłowym. Błędne utożsamienie indukcji z abstrakcją utrzymywało się aż do czasów Kanta i nawet w filozofii Kanta znajdujemy echa doktryny Arystotelesowskiej w postaci nauki o dwóch pniach poznania naoczności i intelekcie. Nelson diagnozuje, że Arystoteles nie dostrzegał problemów logiki i empirii polegających na tym, że sama logika formalna jest pusta, a sama empiria nie może być samodzielnym źródłem poznania. Historyczną zasługą Kant jest dostrzeżenie tych błędów, gdyż doszedł on do wniosku, że doświadczenie bez pojęć jest ślepe, a pojęcia bez doświadczenia są puste:

Żadnej z tych własności [zmysłowości i intelektu - T.K.] nie należy wynosić nad drugą. Bez zmysłowości żaden przedmiot nie byłby nam dany, zaś bez intelektu pomyślany. Myśli bez intelektu są puste, zaś oglądy bez pojęć ślepe. ${ }^{31}$

Kant zaproponował trzecią drogę metody krytycznej w opozycji do - opartego na dychotomii zmysłowości i intelektu - dualizmu dedukcji i indukcji, to znaczy wobec metody progresywno-matematycznej niemieckiego racjonalizmu oraz metody indukcyjno-psychologicznej brytyjskich empirystów. Metoda kry-

\footnotetext{
${ }^{29}$ Por. tamże, s. 51.

${ }^{30}$ Tamże, s. 51 i nast.

${ }^{31}$ I. Kant, Dziela zebrane. Krytyka czystego rozumu, tłum. M. Żelazny, Wydawnictwo Naukowe UMK, Toruń 2013, t. 2, s. A51 / B75.
} 
tyczna Kanta polega $\mathrm{z}$ jednej strony na ustalaniu podstaw lub metafizycznym roztrząsaniu (Grundlegung oder metaphysische Erörterung) przez wyszukiwanie pryncypiów na drodze logicznej analizy sądów apodyktycznych a z drugiej - na wykazującej prawomocność tych sądów w dedukcji transcendentalnej.

Kluczem do zrozumienia metody regresywnej w ujęciu Nelsona jest przyjęcie istnienia nienaocznego poznania bezpośredniego, które dostarcza podstaw wszelkiego poznania pośredniego zawartego w refleksji czy w sądach ${ }^{32}$. Nelson uważa bowiem, że:

Poznanie bezpośrednie nie może być przedmiotem sporu, jego pewności nie można kwestionować i podejrzewać o błąd, błąd bowiem jest jedynie wypaczeniem bezpośredniego poznania, fałszywym powtarzaniem bezpośredniego poznania, fałszywym wypowiadaniem bezpośredniego poznania. ${ }^{33}$

To pryncypium bezpośredniego poznania stanowi podstawę metody krytycznej, chociaż jej założenie jako niekrytyczne (czyli dogmatyczne) krytykuje Ernst Cassirer.

Nelson w swojej koncepcji poznania bezpośredniego jako niepodważalnej podstawy naszego poznania wychodzi jednak od typowo neokantowskiego odrzucenia teorii odbicia, gdy stwierdza:

Zgodność z przedmiotem nie może być dla nas nigdy kryterium prawdziwości naszego poznania, gdyż w tym celu musielibyśmy wykroczyć poza nasze poznanie, aby móc je porównać z przedmiotem, co nie jest możliwe, gdyż do przedmiotu dochodzimy zawsze dopiero poprzez poznanie. ${ }^{34}$

To oznacza, że nie przedmiot wyznacza, które poznanie jest prawdziwe, lecz samo (bezpośrednie) poznanie. W porządku poznania przedmiot jest czymś wtórnym, to znaczy staje się nim dopiero wtedy, gdy poznanie jest bezpośrednie, czyli nie powątpiewalne, bezbłędne a przede wszystkim prawdziwe. Zakładana przez korespondencyjną teorię prawdy teoria odbicia przyjmuje, że można porównać dwie tak zasadniczo różne człony relacji poznawczej, jak poznanie i jego przedmiot. To jest nie możliwe, gdyż porównywać można między sobą tylko

${ }^{32}$ Zob. L. Nelson, „Metoda krytyczna i stosunek psychologii do filozofii”, dz. cyt., s. 57 i nast.

${ }^{33}$ Tamże, s. 58.

${ }^{34}$ Tamże. 
poszczególne poznania, spośród których poznanie bezpośrednie jest epistemicznie uprzywilejowane przez to, że nie można zakwestionować jego prawdziwości: „Wątpienie w poznanie bezpośrednie prowadzi do sprzeczności”, ponieważ musi zakładać podstawę w postaci jakiegoś poznania bezpośredniego. Nie ma alternatywy między prawdziwym albo fałszywym poznaniem bezpośrednim, lecz tylko alternatywa między tym, że coś jest bezpośrednim poznaniem albo nim nie jest. A także problematyczne jest poznanie pośrednie. Takie rozumienie prawdziwości poznania prowadzi Nelsona do wniosku, że w filozofii ostatecznie chodzi o pytanie, co jest bezpośrednim poznaniem czystego rozumu.

\section{Matematyka krytyczna}

Inspiracje dla getyngeńskiej koncepcji matematyki krytycznej Nelsona i Hessenberga pochodzily wprawdzie z Grundlagen der Geometrie Hilberta, który był uznawany również za zwolennika matematyki krytycznej, ale jej źródła sięgały jeszcze dalej do rozprawy Friesa Mathematische Naturphilosophie z 1822 roku. Peckhaus uważa, że:

Można pokazać, że Hilbertowska aksjomatyka geometrii służy jako wzór dla matematycznych składników matematyki krytycznej, którą należy rozumieć w kontekście filozoficznych dążeń neofriesjanistów jako »filozoficzną podbudowę«.

Peckhaus swoje przekonanie uzasadnia podając następujące argumenty. Hessenbarg już w 1903 przedstawił wykład Über die kritische Mathematik w ramach Berlińskiego Towarzystwa Matematycznego ${ }^{36}$. Krytyczność oznacza dla Hessenberga krytyczne badanie wstępne systemów aksjomatycznych na wzór krytyki Kanta oraz dokonań Gaußa. Badania dotyczą takich podstawowych kwestii jak (1) logiczne powiązania aksjomatów, (2) ich dedukcja oraz (3) źródła poznania. Hessenberg uznaje, że kryteriami aksjomatyczności są nie tylko bezpośrednia oczywistość, lecz również - tak jak u Hilberta - niezależność, nie-

${ }^{35}$ „Es läßt sich zeigen, daß die Hilbertsche geometriche Axiomatik als Vorbild für die mathematische Komponente der Kritischen Mathematik diente, die im Rahmen der philosophischen Bemühungen der Neofriesianer mit einem "philosophischen Unterbau« versehen werden sollte." V. Peckhaus, Hilbertprogramm und Kritische Philosophie..., dz. cyt, s. 158-159.

${ }^{36}$ Por. tamże, s. 159. 
sprzeczność oraz zupełność. Niesprzeczność aksjomatów ma zagwarantować ich logiczny formalizm a w konsekwencji również ich logiczną niezależność. Arytmetyzacja systemu aksjomatów ma pokazać możliwości ich zastosowania w dziedzinie liczb. Hessenberg był przekonany, że arytmetyzacja doprowadzi do jasnego, ścisłego i precyzyjnego sformułowania geometrycznej naoczności a tym samym do dalszego postępu badań geometrycznych. W ujęciu dedukcji aksjomatów Hessenberg niejasno odwoływał się do badań psychologicznych nad trójwymiarowości przestrzeni przedstawionych przez - reprezentanta pierwszej Szkoły Friesa - Ernsta Friedricha Apelta w jego Metaphysik ${ }^{37}$. Źródła poznania matematycznych aksjomatów Hessenberg upatrywał w Kantowskiej „,czystej naoczności” i w jej ujęciu przez Hermanna von Helmholza. W ten sposób w ramach matematyki krytycznej spotykają się matematyka $\mathrm{z}$ filozofią.

Wywołany przez Hessenberga Nelson odnosi się do koncepcji matematyki krytycznej w swoim dwuczęściowym artykule Bemerkungen über die NichtEuklidische Geometrie und den Ursprung der mathematischen Gerwißheit opublikowanym w Abhandlungen der Fries'schen Schule w 1906 roku $^{38}$. Nelson odnosi się w nim do dyskusji nad geometrią nieeuklidesową a tytułowa kwestia źródeł nie tylko geometrycznej, lecz również arytmetycznej - czyli matematycznej - pewności zostaje ujęta w duchu matematyki krytycznej. Punktem wyjścia jest Kantowski podział na sądy analityczne (definicyjne) i syntetyczne, by dojść do wniosku, że „Matematyczne aksjomaty i wszystkie oparte na nich teorematy są sądami syntetycznymi. ${ }^{\prime 39}$ Nelson rozumie zatem sądy matematyki po Kantowsku jako sądy syntetyczne a priori, których źródłem poznania jest czysta, bezpośrednio oczywista, niezmysłowa i nieempiryczna naoczność. Spośród wszystkich tego rodzaju sądów matematycznych Nelson nazywa aksjomatami tylko te, które nie mogą zostać dowiedzione, to znaczy nie mogą zostać wyprowadzone $\mathrm{z}$ bezpośrednio oczywistych aksjomatów w skończonej liczbie czysto sylogistycznych operacji. Dodatkowo zakłada on, że liczba tego rodzaju aksjomatów powinna być z jednej strony możliwie mała a poszczególne aksjomaty niezależne od sie-

${ }^{37}$ E.F. Apelt, Metaphysik, W. Engelmann, Leipzig 1857.

${ }^{38}$ L. Nelson, Bemerkungen über die Nicht-Euklidische Geometrie und den Ursprung der mathematischen Gewißheit, „Abhandlungen der Fries'schen Schule. Neue Folge”, 1906, t. 1, nr 2 and 3, s. 373-392, 393-430.

${ }^{39}$ L. Nelson, Bemerkungen über die Nicht-Euklidische Geometrie und den Ursprung der mathematischen Gewißheit, [w:] Gesammelte Schriften in neun Bänden: Die kritische Methode in ubrer Bedeutung für die Wissenschaft, Meiner Verlag, Hamburg 1974, t. 3, s. 11. 
bie, lecz z drugiej strony wszystkie twierdzenia danej nauki muszą być możliwe do wyprowadzenia $z$ nich bez użycia dodatkowych twierdzeń (aksjomatów). Przy czym kryterium logicznej niezależności aksjomatów stanowi niesprzeczność systemu aksjomatów. Konsekwencje tak przyjętych założeń dotyczących niezależności aksjomatów Nelson dostrzega w postulacie równoległości (Parallelensatz), który jest pewną postacią postulatu Euklidesa ${ }^{40}$. Postulat równoległości, pozwalający odróżnić geometrię euklidesową od nieeuklidesowych, jest niesprzeczny z pozostałymi aksjomatami, a zatem aksjomat ten jest niezależny od pozostałych. Z możliwości geometrii nieeuklidesowej Nelson wyciąga wniosek w duchu Kantowskiej filozofii matematyki - o nielogicznym źródle aksjomatów. Krytykuje on przy tym wniosek Helmholtza, że jeżeli aksjomaty matematyki nie mogą mieć logicznego źródła, to muszą mieć źródło empiryczne ${ }^{41}$. Uważa tak, gdyż przyjmuje, że do zawartych w aksjomatach pojęć podstawowych nie można dotrzeć na drodze indukcji, lecz jedynie przez abstrakcję z doświadczenia ${ }^{42}$.

Nelson uznaje postulat logicyzacji matematyki tylko w tym znaczeniu, że prawdy matematyczne muszą spełniać negatywne warunki logiki, choć sama logiczna niesprzeczność nie wystarcza do uznania, że dany byt matematyczny istnieje ${ }^{43}$. Logika nie może zdecydować o istnieniu pojęć matematycznych. Żeby przypisać zdefiniowanym pojęciom - zawartym $\mathrm{w}$ aksjomatach - istnienie należy dodać syntetyczny aksjomat o istnieniu danego pojęcia. Jest to możliwe tylko wtedy, gdy tak zdefiniowane obiekty są możliwe, czyli stanowią niesprzeczny system $^{44}$. W tym kontekście Nelson odnosi się do Grundlegung der Arithmetik Hilberta i stwierdza:

Wydaje się zatem, że Hilbert w swej realizacji zamierzeń wobec podstaw arytmetyki nieuchronnie zmierza do naszego krytycznego ujęcia. ${ }^{45}$

Nelsona koncepcja matematyki krytycznej pozostaje w ścisłym związku z koncepcją Hilberta.

${ }^{40}$ Por. tamże, s. 16.

${ }^{41}$ Por. tamże, s. 24.

${ }^{42}$ Por. tamże, s. 29 i nast.

${ }^{43}$ Tamże, s. 41 i nast.

${ }^{44}$ Tamże., s. 43.

45 „Es scheint daher die Durchführung der neuerdings von HILBERT ausgehenden Bestrebungen rücksichtlich der Grundlagen der Arithmetik unvermeidlich gerade zu der von uns vertretenen kritischen Auffassung zu drängen.” Ibid. (Fußnote 18). 
Podstawowe założenia artykułu Nelsona z 1905 roku zostały przedstawione w bardziej przystępnej formie w tekście Kant und die Nicht-Euklidische Geometrie opublikowanym w czasopiśmie Weltall. Illustrierte Zeitschrift für Astronomie und verwandte Gebiete z 1906 roku. Nelson prezentuje w nim podwójne zadanie matematyki krytycznej, które polegać ma po pierwsze na regresywnym wynajdywaniu twierdzeń podstawowych w teoriach matematycznych a po drugie - dedukcji tych aksjomatów. Pierwsze zadanie ma charakter aksjomatyczny w sensie Hilbertowskim ${ }^{46}$. Zadanie matematyki krytycznej nie polega jednak tylko na wykazaniu aksjomatów dla przyjętych prawd, lecz obejmuje również odpowiedz na filozoficzne pytanie o źródło aksjomatów oraz ich ważność. Oba zadania łączy metoda regresywna.

Nelson przeciwstawia swoją koncepcję krytycznego ugruntowania matematyki innym stanowiskom takim jak logicyzm, konwencjonalizm oraz empiryzm. Peckhaus uważa, że w Nelsonowskiej koncepcji matematyki Hilberta program aksjomatyzacji pełni funkcję paradygmatyczną ${ }^{47}$. Wyraźnie podkreślił to Nelson w swoim referacie Kritische Philosophie und mathematische Axiomatik wygłoszonym na miesiąc przed jego przedwczesną śmiercią 28 września 1927 roku. Istotne znaczenie aksjomatyki wynika $z$ postulowanego przez niego ścisłego rozróżnienie tego, co możliwe do dowiedzenia i założeń przyjętych dowodów. Nelson stara się w ten sposób połączyć Friesa koncepcję metody dedukcyjnej z programem Hilberta.

Początek tego przekonania Nelsona o zgodności filozofii neofriesjańskiej z filozoficzno-matematycznymi założeniami Hilberta Peckhaus sytuuje w lecie $1905 \mathrm{roku}^{48}$. Świadczy o tym przytoczona przez niego korespondencja, w której Nelson daje wyraz swemu rozczarowaniu filozoficznym zapleczem „rezultatów” Hilberta, a za godną podziwu uznaje jedynie ich matematyczną stronę. Zarzuca mu, że nie zna krytycznego - opartego na sądach syntetycznych a priori - ujęcia kwestii źródeł i nie rozważa jej możliwości. Przeciwnego zdania jest adresat korespondencji Hessenberg, który uznaje metody i rezultaty Hilberta za wybitne, usprawiedliwiając jego nieznajomość problemu źródła poznania tym, że należą one do psychologii, a nie do logiki. Nelson stopniowo jednak zostaje przekona-

${ }^{46}$ L. Nelson, Kant und die Nicht-Euklidische Geometrie, [w:] Gesammelte Schriften in neun Bänden: Die kritische Methode in ubrer Bedeutung für die Wissenschaft, Meiner Verlag, Hamburg 1974, t. 3, s. 58.

${ }^{47}$ Por. V. Peckhaus, Hilbertprogramm und Kritische Philosophie..., dz. cyt., s. 165.

${ }^{48}$ Tamże, s. 166 i nast. 
ny przez Hessenberga do stanowiska Hilberta i w korespondencji z sierpnia 1905 roku odwołuje swoje zastrzeżenia. Nelson dostrzega również, że koncepcja matematyki krytycznej spełnia Hilbertowski postulat rozwiązywalności dowolnego matematycznego problemu, aczkolwiek uznaje, że nie wystarczą do tego wyłącznie metody matematyczne i logiczne, gdyż potrzebne jest jeszcze krytyczne pytanie o źródła. W ten sposób Nelson został stopniowo przekonany przez swojego przyjaciela Hessenberga o dużym potencjale matematycznego programu aksjomatyzacji Hilberta.

W Getyndze Nelson związał się ze środowiskiem matematycznym, do którego należeli David Hilbert, Richard Courant, Ernst Zermelo, Felix Klein, Hermann Minkowski, Carl Runge, fizyk Max Born, lekarz Arthur Kronfeld, a także fizjolog Otto Meyerhof. Jego niepokorny charakter oraz środowiskowe animozje wpłynęły na losy jego kariery naukowej. Pierwsza próba habilitacji w 1906 roku na podstawie traktatu Die kritische Methode und das Verbältnis der Psychologie zur Philosophie (1904) zakończyła się niepowodzeniem. Habilitował się dopiero za drugim razem w 1908 roku na podstawie rozprawy Untersuchungen zur Entwicklungsgeschichte der Kantischen Erkenntnistheorie. Habilitacja nie zmieniła jednak wiele w jego karierze zawodowej, gdyż profesurę otrzymał dopiero dziesięć lat później w 1918 roku i aż do śmierci w 1927 roku nie uzyskał pełnej profesury i własnej katedry filozofii. Nelson w liście Hilberta z 1916 roku skarżył się, że nie może promować swoich uczniów na filozofii. Wielu z nich habilitowało się na matematyce, fizyce, psychologii, a nawet na teologii, tylko nie na filozofii. Można powiedzieć, że Nelson w pewnym sensie zawdzięcza swoją habilitację autorytetowi Hilberta, który zajmował ważną pozycję na Uniwersytecie w Getyndze. Hilbert bowiem wysoko cenił pracę Bemerkungen zu den Paradoxien von Russell und Burali-Forti, którą Nelson opublikował w 1908 roku razem z Kurtem Grellingiem ${ }^{49}$.

${ }^{49}$ Kurt Grelling (1886-1942) pochodził z berlińskiej rodziny adwokackiej, a jego ojciec Richard był żydowskim konwertytą wyznania ewangelickiego. W 1905 roku Grelling przeniósł się do Getyngi, gdzie zaprzyjaźnił się z Nelsonem. Duże wrażenie na Grellingu zrobiły wykłady Zermelo z logiki matematycznej, na które uczęszczał w semestrze letnim 1908 roku. Grelling złożył w maju 1910 roku swoją, rozprawę doktorską pod tytułem Die Axiome der Aritbmetik unter besonderer Berücksichtigung der Beziehungen zur Mengenlehre na Wydziale Filozofii Uniwersytetu w Getyndze. Pracę wprawdzie recenzował David Hilbert, ale przesłał ją wykładającemu w Zurychu Zermelo do oceny. Grelling naukowo zajmował się głównie filozofią matematyki a jego najważniejszą pracą był napisany wspólnie z Nelsonem artykuł z 1908 roku. Artykuł ten powstał jeszcze przed jego rozprawą doktorską a po doktoracie zajmował się friesowską filozofią matematyki i fi- 
Praca z 1908 roku była wynikiem dyskusji między neofriesjanistami i pierwotnie ukazała się na łamach redagowanego przez nich czasopisma Abhandlungen. Nelson i Grelling próbują w swoje pracy określić kryteria możliwości rozwiązania teoriomnogościowych ${ }^{50}$. Autorzy analizują przede wszystkim teoriomnogościowe antynomie Russella i Burali-Fortiego oraz logiczną antynomię nieorzekalności (Imprädikabilitätsantinornie). Mianem antynomia Russella określa się sprzeczność wykazaną przez Bertranda Russella w 1901 roku, która zadała duży cios dla rozwoju aksjomatyzacji matematyki i logicyzmu. Źródłem paradoksu jest autoreferencja zbioru wszystkich zbiorów, który sam nie może być elementem zbioru. Antynomia Burali-Fortiego polega na tym, że nie istnieje zbiór, którego elementami są wszystkie liczby porządkowe, i pojawiła się pierwotnie w 1897 roku u Cesarego Buralego-Fortiego, ucznia Giuseppe Peana. Antynomia nieorzekalności została sformułowana również przez Russella w 1907 roku. Przyjął on, że pojęcie może być orzekalne, jeśli przynależy do siebie samego jako cecha albo nieorzekalne, gdy jest przeciwnie. Russell wykazał, że sama nieorzekalność jest zarazem orzekalna i nieorzekalna, co prowadzi do sprzeczności. Nelson i Grelling uogólnili te trzy antynomie do jednej ogólniejszej postaci.

Zdaniem Peckhausa dyskusja nad antynomiami w ramach Nowej Szkoły Friesa jest jeszcze wcześniejsza niż rozprawa Grellinga i Nelsona, gdyż sięga jeszcze 1905 roku, kiedy Hessenberg przygotował rozprawę pod tytułem Das Unendliche in der Mathematik do pierwszego zeszytu Abhandlungen... ${ }^{51}$. Hessenberg podejmuje w niej dyskusję nad pojęciem nieskończoności w geometrii i w analizie matematycznej. Nelson mocno skrytykował ujęcie Hessenberga,

lozoficznymi podstawami rachunku prawdopodobieństwa. W 1922 roku Nelson i Grelling pokłócili się o sprawy organizacyjne Międzynarodowego Związku Młodych (Internationalen JugendBundes). Nieco wcześniej rozeszły się również ich filozoficzne drogi i Grelling odszedł od Friesjanizmu, gdy podczas konferencji Towarzystwa Friesowskiego 16 sierpnia 1921 roku Grelling wygłosił referat pod tytułem Relativitätstheorie und kritische Philosophie, w którym nawiązując do poglądów Hansa Reichenbacha wyraźnie zdystansował się wobec filozofii krytycznej. Później te różnice stały się jeszcze bardziej wyraźne i podczas konferencji w 1929 roku w Pradze zdecydowanie odrzucił możliwość sądów syntetycznych a priori, stwierdzając, że a priori mogą być tylko tautologie. Podstawowe pryncypia nauki mogą być dla niego tylko logiczne albo empiryczne. Zginął w KZ Auschwitz.

${ }^{50}$ L. Nelson i K. Grelling, Bemerkungen zu den Paradoxien von Russell und Burali-Forti, „Abhandlungen der Fries'schen Schule. Neue Folge”, 1908, t.2, s. 301-334.

${ }^{51}$ Por. V. Peckhaus, Hilbertprogramm und Kritische Philosophie..., dz. cyt., s. 177. 
który odpowiedział mu zarzutem braku wiedzy na temat teorii mnogości. To zmotywowało Hessenberga do przygotowania czytelnej dla filozofów prezentacji podstawowych założeń teorii mnogości, która podejmie kwestię paradoksów przeliczalności kontinuum. Ważną inspiracją dla badań i dyskusji neofriesjanistów była też publikacja Russellowskich Principles of Mathematics z 1903 roku, a także krytyka jej teorio zbiorowych założeń podjęta przez Poincaré. Hessenberg w korespondencji z Nelsonem uznaje słuszność zarzutów Poincarégo i wiążąc wielkie nadzieje z jego koncepcją, wyraża przypuszczenie, że rozwiązania paradoksów należy poszukiwać $\mathrm{w}$ definicjach zawierających błąd circulus vitiosus. Sam Hessenberg w rozdziale Ultrafinite Paradoxieen swojej Mengenlebre przedstawia paradoksy ultrafinitystyczne jako antynomie dotyczące zbiorów. Rozróżnia zbiory ultrafinitystyczne i transfinitystyczne. Zauważa, że Russellowski paradoks niezawierającego samego siebie zbioru wszystkich zbiorów wykracza poza matematykę i nie można go uznawać za zbiór wszystkich rzeczy. Matematyczny pozostaje paradoks Burali-Fortiego, który operuje na zbiorze wszystkich liczb porządkowych, w stosunku do którego uznaje, że źródła trudności należy poszukiwać w pojęciu zbioru. Hessenberg nie wierzył w możliwość podjęcia i rozwiązania Russellowskich antynomii za pomocą środków logicznych, tak jak to próbowali uczynić Grelling i Nelson, gdyż uważał, że wymaga to raczej dalszej pracy na gruncie teorii mnogości. Szczegółowa analiza rozwiązań matematycznych zaproponowanych przez Grellinga i Nelsona oraz innych neofriesjanistów wykracza poza ramy przyjęte w niniejszej rozprawie.

\title{
ORIGIN AND FOUNDATION OF LEONARD NELSON'S PHILOSOPHY OF CRITICAL MATHEMATICS
}

\begin{abstract}
Summary
The article concerns the history of philosophical relationships between philosophers and mathematicians associated with the New Friesian School. The aim is to show the complex relationship between the doctrines of the philosophical precursors of this school, such as Immanuel Kant, Jakob Friedrich Fries and Ernst Friedrich Apelt, as well as the presentation of the major philosophical-mathematical inspirations of the mathematician such as David Hilbert. Nelson's mathematical and philosophical relationships with Gerhard Wilhelm Hessenberg and Kurt Grelling have influenced the Neo-Friesian philosophy of critical mathematics.
\end{abstract}


Key words: philosophy of mathematics, Neo-Friesian School, Neo-Friesianism, Leonard Nelson, Immanuel Kant, Jakob Friedrich Fries, Ernst Friedrich Apelt, David Hilbert, Gerhard Wilhelm Hessenberg, Kurt Grelling

Słowa kluczowe: filozofia matematyki, Nowa Szkoła Friesa, neofriesjanizm, Leonard Nelson, Immanuel Kant, Jakob Friedrich Fries, Ernst Friedrich Apelt, David Hilbert, Gerhard Wilhelm Hessenberg, Kurt Grelling

\section{Bibliografia}

Apelt E.F., Metaphysik, W. Engelmann, Leipzig 1857.

Apelt E.F., Schleiden M.J., Schlömilch O.X., i Schmidt O., Abhandlungen der Fries'schen Schule, Verlag von Wilh. Engelmann, Leipzig 1847, t. 1.

—, Abhandlungen der Fries'schen Schule, Verlag von Wilh. Engelmann, Leipzig 1849, t. 2.

Chisholm R.M., Die sokratische Methode und die Erkenntnistheorie, „Ratio”, 1979, nr 21, s. 97-108. Fries J.F., Neue Kritik der Vernunft, Mohr und Zimmer, Heidelberg 1807, t. I.

—, Entwurf des Systems der theoretischen Physik. Zum Gebrauche bey seinen Vorlesungen, Mohr und Zimmer, Heidelberg 1813.

- Die mathematische Naturphilosophie nach philosophischer Methode bearbeitet: ein Versuch, Mohr und Winter, Heidelberg 1822.

—, System der Logik: Ein Handbuch für Lehrer und zum Selbstgebrauch, Mohr und Zimmer, Heidelberg 1837, 3. wyd.

Hessenberg G., Kaiser K., i Nelson L., Abhandlungen der Fries'schen Schule. Neue Folge, Vandenhoeck \& Ruprecht 1906, t. 1.

Jakob Friedrich Fries, Versuch einer Kritik der Principien der Wahrscheinlichkeitsrechnung, Friedr. Vieweg u. Sohn, Braunschweig 1842.

Kant I., Dziela zebrane. Krytyka czystego rozumu, przeł. M. Żelazny, Wydawnictwo Naukowe UMK, Toruń 2013, t. 2.

Kubalica T., Die Beziehung zwischen dem Lehrmeister und dem Schüler in der neukantischen Philosophie, „Idea - Studia nad Strukturą i Rozwojem Pojęć Filozoficznych”, 2015, t. XXVII, s. 384-394.

Kubalica T., Leonard Nelson and Metaphysical Knowledge against the Neo-Kantian Background, „Diametros”, 2017, nr 52, s. 64-80 (DOI: 10.13153/diam.52.2017.1059).

Kubalica T., Unmöglichkeit der Erkenntnistheorie. Leonard Nelsons Kritik an der Erkenntnistheorie unter besonderer Berücksichtigung des Neukantianismus, Peter Lang, Frankfurt am Main 2017 (DOI: dx.doi.org/10.3726/b10702).

Nelson L., Bemerkungen über die Nicht-Euklidische Geometrie und den Ursprung der mathematischen Gewißheit, „Abhandlungen der Fries'schen Schule. Neue Folge”, 1906, t.1, nr 2 and 3, s. 373-392, 393-430.

—, Die sogenannte neukantische Schule in der gegenwärtigen Philosophie, [w:] Gesammelte Schriften in neun Bänden: Die Schule der kritischen Philosophie und ibre Methode, Hamburg 1970, t. 1, s. 207-217. 
- Bemerkungen über die Nicht-Euklidische Geometrie und den Ursprung der mathematischen Gewißheit, [w:] Gesammelte Schriften in neun Bänden: Die kritische Methode in ubrer Bedeutung für die Wissenschaft, Meiner Verlag, Hamburg 1974, t. 3, s. 3-52.

-, Kant und die Nicht-Euklidische Geometrie, [w:] Gesammelte Schriften in neun Bänden: Die kritische Methode in uhrer Bedeutung für die Wissenschaft, Meiner Verlag, Hamburg 1974, t. 3, s. 53-94.

—, Metoda sokratyczna, [w:] O sztuce filozofowania, przeł. P. Waszczenko i T. Kononowicz, Wydawnictwo Baran i Suszyński, Kraków 1994, s. 159-205.

-, Metoda krytyczna i stosunek psychologii do filozofii, [w:] O sztuce filozofowania, przeł. P. Waszczenko i T. Kononowicz, Wydawnictwo Baran i Suszyński, Kraków 1994, s. 43113.

Nelson L., i Grelling K., Bemerkungen zu den Paradoxien von Russell und Burali-Forti, „Abhandlungen der Fries'schen Schule. Neue Folge", 1908, t.2, s. 301-334.

Nelson L., Hessenberg G., i Kaiser K., Vorwort der alten Folge zugleich als Vorwort der neuen Folge, „Abhandlungen der Fries'schen Schule. Neue Folge”, 1904, t.1, nr 1, s. III-XII.

Noras A.J., Historia neokantyzmu, Wydawnictwo Uniwersytetu Śląskiego, Katowice 2012.

Peckhaus V., Hilbertprogramm und Kritische Philosophie. Das Göttinger Modell interdisziplinärer Zusammenarbeit zwischen Mathematik und Philosophie, Vandenhoeck \& Ruprecht, Göttingen 1990.

Schroth J., Regressive Methode der Abstraktion und unmittelbare Erkenntnis bei Leonard Nelson, [w:] Leonard Nelson in der Diskussion, red. R. Kleinknecht i B. Neißer, Dipa-Verlag, Frankfurt am Main 1994, t. 1, "Sokratisches Philosophieren«Schriftenreihe der PhilosophischPolitischen Akademie, s. 114-152.

Wahler H., Sokratische Methode - Sokratischer Dialog - Sokratisches Gespräch. Zur Anwendung in Philosophischer Psychologie Praxis, Pädagogik und Psychotherapie, „e-Journal Philosophie der Psychologie", b.d., s. 1-10.

dr hab. Tomasz Kubalica, Instytut Filozofii, WNS UŚ w Katowicach 